\title{
Comparison between Haemagglutination Inhibition and Complement Fixation Tests in Detecting Antibodies Responses Following Influenza Viral Infection
}

\author{
Muthana, A.K. Al-zobaei
}

Medical Microbiology, Microbiol. Dept. Virology, College of Medicine, Univ. Anbar.

\begin{abstract}
Objectives: To evaluate sensitivity and specificity of $\mathrm{HI}$ and $\mathrm{CF}$ tests for detecting antibody responses following naturally occurring influenza A and B infections.

Methods: One hundred and twenty blood samples were drawn from one hundred patients with flue-like illness and twenty apparently healthy control subjects and tested at Central Health Laboratory in Baghdad/ Iraq using HI and CF tests for detecting three currently circulating influenza A and B strains during the period from the $1^{\text {st }}$ of January 2008 to the $1^{\text {st }}$ of June 2009.

Results: $78-80 \%$ of the patients with flu-like illness responded to a t least one of three influenza virus antigens as measured by HI, while $34-35 \%$ of those patients showed a response by $\mathrm{CF}$ test.
\end{abstract}

Conclusions: HI test has a higher sensitivity and lower specificity than CF test for detecting antibody responses from patients with influenza $\mathrm{A}$ and $\mathrm{B}$ viral infections.

Keywords : Influenza viruses, HI, CF, Influenza serology

\section{INTRODUCTION}

Several studies have clearly demonstrated that $\mathrm{HI}$ is a more sensitive method than $\mathrm{CF}$ test for detecting antibody responses to naturally occurring influenza virus $\mathrm{A}$ and $\mathrm{B}$ infections, Julkunen, I. et al. (1985); Zigler T, et al (1983); Masurel A.et al (1983). Haemagglutination Inhibition test detects antibodies to strain-specific haemagglutinins, whereas CF test mainly detects antibodies to type specific nucleoproteins, Julkunen, I. et al.(1985). Haemagglutinins are used as antigens in influenza virus, this making $\mathrm{HI}$, the method of choice for measuring influenza virus infection, Madora et al.(1983); Palmer D.F And Whaley S.D (1986); Pyhala R. and Kleemola M. (1976); Sever J.L (1962).

The key test is HI, which depends on the ability of the virus to agglutinate human group ' $\mathrm{O}$ ' or chicken erythrocyte and inhibition of this process by specific antibody. Diagnosis required at least a fourfold rise in antibody titer, Julkunen, I. et al. (1985) ;Palmer DF And Whaley
SD. (1986), whereas CF test based on fixation of complement by antigenantibody complexes. A known amount of complement is included in the test and residual complement is detected by the addition of sheep RBCs sensitized with specific hemolysin. Absence of hemolysis indicates fixation complement and the presence of an antigen-antibody reaction, Pyhala R. and Kleemola M (1976); Sever JL (1962).

Because HI Assays for influenza virus antibodies are not widely available, clinicians often whether $\mathrm{CF}$ is an acceptable method for assessing the influenza infection responses of their patients. Although the point assays to monitor the influenza virus infections, search of the National Library Medicine database did not identify any reports directing comparing $\mathrm{CF}$ and $\mathrm{HI}$ for detecting influenza virus infection induce antibodies, MMWR, (2005).

The aim of this study was conducted to evaluate the $\mathrm{HI}$ and CF tests for measuring antibody response for influenza virus infection and to provide 
comparative data for dissemination for inquiring clinicians.

\section{MATERIALS AND METHODS}

One hundred and twenty blood samples were drawn from one hundred patients with flu-like illness in addition to twenty apparently healthy subjects as a control group during a period between 1 st of January 2008 to the 1st of June 2009 in Central Health Laboratory in Baghdad /Iraq. Three $\mathrm{ml}$ of venous blood were taken aseptically from each patients and transferred to clean and dry plane tube (without anticoagulant) for serum collection after clotting and centrifuged the blood at $2500 \mathrm{rpm}$ for 5 minutes pooled serum was kept in Eppendorf tubes at $-20 \mathrm{c}$. to be used.

Three strains of influenza viruses currently causing infections in the world were used: These were influenza A/Brisbane/59/2007 (H1N1)-like antigen, influenza A/Brisbane/10/2007 (H3N2)-like antigen and influenza B/Florida/4/2006like antigen. The Haemagglutination inhibition (HI) antibody test was carried out by standard procedures, using the microtiter methods, Masurel, A. and Heijtink AA. (1983).

Prior to HI testing, the sera were treated with cholera filtrate for 18 hours and subsequently heated at $56^{\circ} \mathrm{C}$ for 60 minutes, in $\mathrm{HI}$ test eight haemagglutination units (8HA units) were used as antigen and reference antisera were included in each test batch. Complement fixation test was carried out by standard procedures using microtiter methods, Sever, JL. (1962). Prior to CF testing, the sera were treated with cholera filtrate for 18 hours, and subsequently heated at $56^{\circ} \mathrm{C}$ for 60 minutes to inactivate complement and the $\mathrm{CF}$ antibody titers were taken as the highest serum dilution which gave $50 \%$ fixation of complement.

\section{RESULTS}

$80 \%$ of the patients exhibit an antibody response to influenza A/Brisbane (H1N1) antigen (Table 1) and influenza A/Brisbane (H3N2) antigen (Table 2) and $78 \%$ of those patients exhibit an antibody responses to influenza B (table 3) using $\mathrm{HI}$ test in contrast to $18-20 \%$ of those patients exhibit negative result using the same test and this result was statistically significant $(p<0.01)$, whereas the responses rates were markedly low using CF test and only $34 \%$ patients showed a respond to influenza $\mathrm{A} /$ Brisbane $(\mathrm{H} 1 \mathrm{~N} 1)$ as showed in (Table 1), 35\% patients showed respond to influenza A/Brisbane (H3N2) using the same test (Table 2 ), and only $21 \%$ of the patients respond to influenza B/Florida/4/2006 like antigen (Table 3).

Table 1: Sensitivity and specificity of HI and CF tests for detecting influenza A /Brisbane/59/2007 (H1N1)-like antigen.

\begin{tabular}{|c|c|c|c|c|}
\hline \multirow{2}{*}{ Test used } & \multirow{2}{|c|}{ Complement fixation } & \multirow{2}{*}{ Total } \\
\cline { 3 - 5 } & & + & 49 & 80 \\
\hline Haemagglutination inhibition & + & 31 & 17 & 20 \\
\cline { 2 - 4 } & & 3 & 66 & 100 \\
\hline Total & \multicolumn{2}{|c|}{$\begin{array}{c}\text { Sensitivity }=38.7 \% \\
\text { Specificity }=85 \%\end{array}$} \\
\hline Sensitivity $=91.2 \%$ & &
\end{tabular}

Table 2: Sensitivity and specificity of HI and CF tests for detecting influenza A /Brisbane/10/2007 (H3N2)-like antigen.

\begin{tabular}{|c|c|c|c|c|}
\hline \multirow[t]{2}{*}{ Test used } & & \multicolumn{2}{|c|}{ Complement fixation } & \multirow[t]{2}{*}{ Total } \\
\hline & & + & - & \\
\hline \multirow[t]{2}{*}{ Haemagglutination inhibition } & + & 35 & 45 & 80 \\
\hline & - & 0 & 20 & 20 \\
\hline Total & & 35 & 65 & 100 \\
\hline $\begin{array}{l}\text { Sensitivity }=100 \% \\
\text { Specificity }=30.8 \%\end{array}$ & & \multicolumn{2}{|c|}{$\begin{array}{l}\text { Sensitivity }=43.7 \% \\
\text { Specificity }=100 \%\end{array}$} & \\
\hline
\end{tabular}


Out of $80 \%$ patients exhibiting $\mathrm{HI}$ response to influenza $\mathrm{A} /$ Brisbane (H1N1), only 31 patients showed $\mathrm{CF}$ response to these strains (table 1), at the same time out of the 20 patients non exhibiting response to these strains, only three of them showed CF response. Out of 80 patients exhibiting an $\mathrm{HI}$ (H3N2), only 35 patients showed CF response to these strains, at the same time
$20 \%$ of the patients not response to HI (table 2 ). Out of $35 \%$ patients exhibiting HI response to influenza $\mathrm{B}$, only one patient showed CF response to influenza $\mathrm{B}$ and 22 of the patients exhibiting non HI influenza B, 21 of them response to influenza B (Table3). All healthy control sera were negative for HI and $\mathrm{CF}$ test against three strains of influenza viruses.

Table 3: Sensitivity and specificity of HI and CF tests for detecting influenza B /Florida/4/2006 -like antigen.

\begin{tabular}{|c|c|c|c|c|}
\hline \multirow{2}{*}{ Test used } & \multirow{2}{|c|}{ Complement fixation } & \multirow{2}{*}{ Total } \\
\cline { 3 - 5 } & & + & 43 & 78 \\
\hline Haemagglutination inhibition & + & 35 & 21 & 22 \\
\cline { 2 - 4 } & - & 1 & 64 & 100 \\
\hline Total & & 36 & \\
\hline Sensitivity $=97.2 \%$ & \multicolumn{2}{|c|}{ Sensitivity $=44.9 \%$} \\
Specificity $=32.8 \%$ & Specificity $=95.4 \%$ & \\
\hline
\end{tabular}

\section{DISCUSSION}

Several studies have shown that the incidence of antibodies against three currently strains of influenza viruses can be measured by sero-epidemiological studies using blood samples collected from patients with flu-like illness MMWR (2009); MMWR (2008). Sera collected and treated with $56^{\circ} \mathrm{C}$ to inhibit complement and this finding was agreement with, Okuno, Y. et al. (1990).

Results in the present study showed that Iraqi persons were infected with influenzaA/Brisbane/59/2007(H1N1)-like antigen, influenza A/Brisbane /10/2007 (H3N2)-like antigen and influenza B/Florida/4/2006-like antigen but the titer of antibody was differ for each strain in spite of the same HA units (8HA units) used in this test as reported by previous studies, Madora, H. et al. (1983); Pyhala R. and Kleemola (1976). and this might be interpreted that each of influenza virus isolates were inhibited with different titers of antibodies in $\mathrm{HI}$ and $\mathrm{CF}$ test and this was provided an evidence for prevalence strains of influenza virus in the world and this was in agreement with the result reported by WHO, MMWR, (2009); MMWR, (2008). Who indicated that these strain was circulating in population during 2008-2009 season.

Using of HI for detecting antibodies against different strains of influenza A and B in the sera of the patients and healthy control group was consistent with other studies, Julkunen, I., et al. (1985); Madora H., et al. (1983); Pyhala R. and Kleemola M.(1976) who reported that this test was more sensitive for detecting antibody responses to naturally occurring influenza $A$ and $B$ viruses and also chosen of $\mathrm{CF}$ test in this research support $\mathrm{HI}$ in diagnosis of influenza viral infection, Julkunen, I., et al. (1985); Zigler T., et al. (1983) ;Azad TM., et al. (2004).

Detection of antibody responses to naturally and experimentally occurring influenza $\mathrm{A}$ and $\mathrm{B}$ viruses using $\mathrm{HI}$ and $\mathrm{CF}$ test was consistent with other reports, Zigler, T. et al. (1983); Madora H., et al. (1983).

From this study we can conclude that $\mathrm{HI}$ testing is superior to $\mathrm{CF}$ testing for detection antibody responses of patients infected with influenza viruses and it's clear that the CF assays give false negative antibody responses results for the majority of patients infected with influenza viruses and influenza A/Brisban/59/2007 (H1N1)-like antigen, influenza A/Brisban/10/2007 (H3N2)-like antigen and influenza B/Florida/4/2006 like antigen was circulating strains during 2008-2009 season.

\section{REFERENCES}

Azad TM., Mohammad h. moosawi Z. Saada I. and Nateah R. (2004). Influenza surveillance in the Islamic Republic of 
Iran from 1991-2001. Estern Mediterranean Health J 10(3):315-321.

Julkunen, I., Pyhala R. and Hovi T. (1985). Enzymeimmunoassay, complement fixation and haemaglutination inhibition tests in the diagnosis of influenza A and B virus infection, purified haemagglutinin in subtype specific diagnosis. J virol Methods, 10:75-84.

Madora H., Reichman R. and Dolin R. (1983) Serum antibody responses to naturally occurring influenza A virus infection determined by enzyme linked immunosorbent assay, hemagglutination inhibition and complement fixation. J Clin Microbiol, 18:1325-1350.

Masurel A. and Heijtink A A. (1983) Recycling of H1N1 influenza viruses in man-a haemagglutinin antibody study. J of Hyge 90: 397-402.

MMWR. Update. (2005). Center for Disease Control. Prevention and Control of influenza :Recommendations of Advisory Committee on Immunization Practice (Acip) 54(8):1-40.

MMWR. Update. (2009). Center for Disease Control. Prevention and Control of influenza :Recommendations of Advisory Committee on Immunization Practice (Acip) 52(8):1-34.
MMWR. Update. (2008). Center for Disease Control. Prevention and Control of influenza: Recommendations of Advisory Committee on Immunization Practice (Acip) 55(8):78-92.

Okuno Y., Tanaka K., Baba k., Maeda A., Kunita N. and Uedas S. (1990). Focus reduction neutralization test of influenza $A$ and $B$ virus microtiter system. J Clin Microbiol 28:1308-1313.

Palmer DF. And Whaley SD. (1986). Complement fixation test. Page: 57-66 in NR. Rose H. Fridman and Fahey (ed).Manual of clinical laboratory immunology. $3^{\text {rd }}$ ed. American Society for microbiology Washington DC.

Pyhala R. and Kleemola M. (1962). The value of complement fixation and haemaggluination inhibition test in the diagnosis of influenza A. Acta Virol 1976, 20:66-69.

Sever JL. Application of a micro-technique to viral serological investigations. $\mathrm{J}$ Immunol 88: 320-329.

Zigler T., Kata J., Cox N. and Regnery H. Influenza viruses. Page:673-678 in Rose NR., Demacario EC., Fold JD., Lane HC. And Nakamura RM. Manual of clinical laboratory immunology. $5^{\text {th }}$ ed 1983. Am Soc for microbiology Washinton DC.

\section{ARABIC SUMMARY}

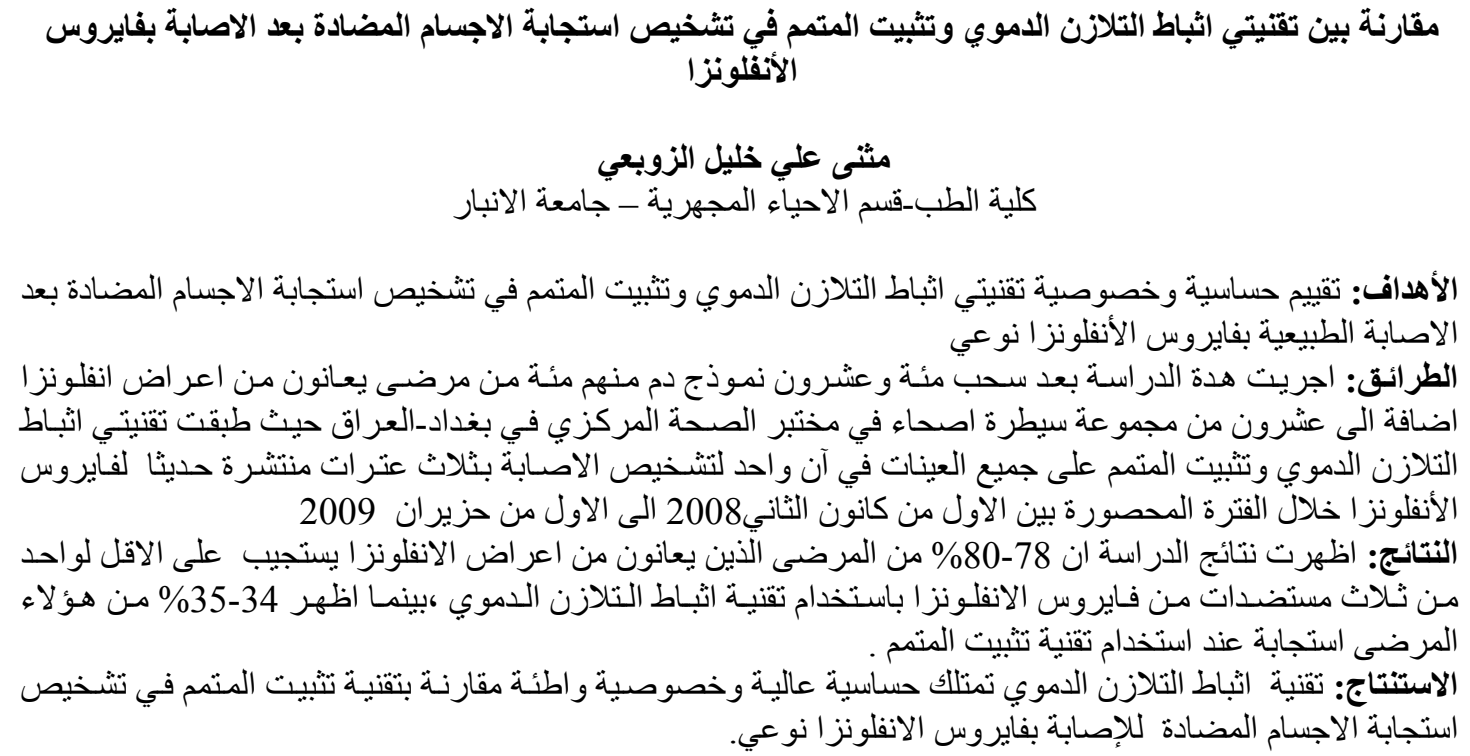

